\title{
Türkiye Muhasebe ve Finansal Raporlama Standartları Konusunda Üniversite Öğrencilerinin Algı Düzeylerinin Ölçülmesi: Bilecik Şeyh Edebali Üniversitesi Örneği*
}

\author{
Meral EROL FİDAN ${ }^{1}$ Taner UYSAL ${ }^{2}$ \\ ${ }^{1}$ Bilecik Șeyh Edebali Üniversitesi İIBF İșletme Bölümü, Bilecik, meral.fidan@ bilecik.edu.tr \\ ${ }^{2}$ Bilecik Şeyh Edebali Üniversitesi İİB SBE İşletme ABD Yüksek Lisans Programı, zonguldak_208013@hotmail.com
}

\begin{abstract}
Özet
Küreselleşen günümüz ortamında, işletmelerin varlıklarını sürdürebilmeleri için aynı dili konuşmaları gerekmektedir. Aynı dili konuşmanın yolu ise Uluslararası Muhasebe Standartları'nı uygulamakla sağlanabilmektedir. Ülkemizde standartlara uyumlaştırma çalışmaları sonucu muhasebe uygulamaları ile mevcut muhasebe uygulamaları arasında farklılıklar olușmaktadır. Meslek adaylarının bu farklılıklar hakkında bilinçlendirilmesi gerekmektedir. Bu nedenle, muhasebe meslek adaylarının söz konusu standartlar hakkında bilgi sahibi olmaları önem arz etmektedir. Yapılan araştırma sonucunda, 20 yaş ve altı ile 21 yaş ve üstü üniversite öğrencileri arasında; işletme, uygulamalı bilimler ve muhasebe ve vergi uygulamaları bölümleri arasında; 2 . sınıflarla 3. ve 4. sınıflar arasında; staj yapmış ve yapmamıș öğrenciler arasında muhasebe standartlarını algılamaları bakımından istatistiki açıdan anlamlı farklılıklar olduğu tespit edilmiştir. Öğrenciler aldıkları muhasebe derslerinde TMS/TFRS'lerden az da olsa bahsedildiğini belirtmekle beraber, genel muhasebe dersini almış öğrencilerin kendi çabalarıyla muhasebe standartlarını öğrenebileceklerine katılmadıkları tespit edilmiştir. Ayrıca öğrencilerin derslerde TMS/TFRS'ler hakkında daha fazla uygulama yapılması gerektiği düşüncesinde oldukları tespit edilmiştir.
\end{abstract}

Anahtar Kelimeler: Türkiye Finansal Raporlama Standartları, TFRS, TMS, Muhasebe Eğitimi.

\section{Measurement Of Perception Level in University Students Regarding Turkish Accounting and Financial Reporting Standards: Bilecik Şeyh Edebali University Case}

\begin{abstract}
In today's globalizing world, businesses are supposed to speak a common language to survive. The way to speak the same language is to adapt to International Accounting Standards. As a result of actions for adaptation to standards in our country, some differences between accounting implementations and current accounting implementations occur. It is crucial to inform prospective accountants at school about such differences. That is why prospective accountants must have an awareness of such standards. Results of the survey revealed that there are statistically significant differences, regarding perception of accounting standards, between students aged 20 or less and students aged 21 or more; between university students of administration, applied sciences departments and accounting and tax applications departments; between $2^{\text {nd }}$ year students and $3^{\text {rd }}$. $4^{\text {th }}$ year students; between students with an internship experience and those without such experience. Students stated that TAS (Turkish Accounting Standards) were taught a little in the courses they attended at school. It was also found out that they do not agree with the idea that students who have previously taken financial accounting course can learn about accounting standards by themselves. Students further commented that more practice about TAS/TFRS should be involved in classes.
\end{abstract}

Key Words: TFRS (Turkish Financial Reporting Standards), TAS (Turkish Accounting Standards), Accounting Education.

\section{Giriş}

Muhasebe, işletmelerin varlıklarının ve kaynaklarının oluşumunu, bunların kullanılma biçimini, işletmelerin yaptığı işlemler sonucunda bu varlıklardaki ve kaynaklardaki değişmeleri, işletmelerin mali durumlarını açıklayacak bilgileri sağlayan ve bu bilgileri ilgili kişi ve kurumlara ileten bir bilgi sistemidir. Muhasebe işletmeler ile ilgili elde etmiş olduğu bilgileri rapor haline getirir ve bu raporlardan elde edilen bilgiler bilgi kullanıcılarına karar almalarında yardımcı olur.

Günümüzün küresel ve rekabetçi iş ortamında, sürekli güncellenen bilgi birikimine sahip olmak, başarı için kaçınılmaz bir anahtar haline dönüşmüştür. $\mathrm{Bu}$ açıdan, iş

'Bu makale Taner UYSAL'ın Doç.Dr. Meral EROL FIDAN danışmanlığında hazırlamış olduğu "Türkiye Muhasebe Ve Finansal Raporlama Standartları Konusunda Üniversite Öğrencilerinin Bilgi Ve Alg Düzeylerinin Ölçülmesi: Bilecik Şeyh Edebali Üniversitesi Örneği” başlıklı yüksek lisans tezinden yararlanılarak hazırlanmıştır. dünyasının her alanında en güncel ve yararlı bilgiye ihtiyaç duyulmaktadır. Öte yandan muhasebe bilgi sisteminden elde edilen bilgiler sadece vergisel açıdan değil yatırım kararları açısından da kullanılmaktadır.

Uluslararası ticaretin gelişmesiyle birlikte, farklı ülkelerde faaliyet gösteren işletmeler, o ülkelerin muhasebe uygulamalarıyla karşı karşıya kalmış ve her ülkedeki muhasebe ilke ve kurallarına göre finansal tablo düzenlemek zorunda kalmışlardır. Ülkeler arası muhasebe uygulamalarındaki farklılıklar ülkelerdeki hukuki ve mali sistemin yapısı, işletmelerin ortaklık yapısı ve buna bağlı olarak finansman yöntemleri, muhasebe mesleğinin gelişmişlik düzeyi, muhasebe bilgileri kullanıcılarının eğitim ve gelişmişlik düzeyi gibi faktörlerden kaynaklanmaktadır.

Türkiye'de hem ulusal hem de uluslararası alanda muhasebe uygulamalarında birliği sağlamak amacı ile 2013 yılından itibaren Türk Ticaret Kanunu'nun yürürlüğe girmesiyle birlikte muhasebe standartları uygulanmaya başlanmıştır Önceleri sadece çeviri boyutunda kalan 
uygulamalar daha sonra ülke koşullarına göre hazırlanarak uygulanmaya çalışılmıştır. Başlangıçta işletmelerin isteğine bırakılan uygulama daha sonra çıkarılan kanun maddeleri ile kapsama giren işletmeler için uygulanması zorunlu hâle getirilmiştir. İlk olarak Türkiye Muhasebe Standartları (TMS) ve Türkiye Finansal Raporlama Standartları (TFRS)'lerin Türkiye'de uygulanmasının zorunlu hâle gelmesi ve uygulanmaya başlanması sermaye piyasası kurulu tarafindan gerçekleştirilmiştir. Sermaye Piyasası Kurulu (SPK)’ya bağlı halka açık işletmeler 2005 yılından itibaren vergi kanunlarına göre yaptıkları finansal raporlamalara ilave olarak TMS ve TFRS'lere göre de raporlama yapmaktadır.

Rekabetin bu denli yoğun yaşandığı günümüz ekonomilerinde işletmelerin muhasebe işlevlerinin de bu değişim ve dönüşümde yeniden organize edilip tanımlanması gerekmektedir. Değişen ekonomik koşullar işletmelerin de muhasebecilerden beklentilerini arttırmaktadır. Muhasebe eğitimi veren temel eğitim kurumları da işletmelerin beklentilerini göz önüne alıp verdikleri muhasebe eğitiminin kalitesini arttırmalı ve piyasa koşullarında uygulanabilirliğini sağlamalıdır. Muhasebe tüm toplumlarda önemli rol oynayan bir alandır. $\mathrm{Bu}$ nedenle, muhasebe, toplumda gerçekleșen değişime ayak uydurmalı ve ortaya çıkan gereksinimleri karşılamalıdır.

Muhasebe eğitiminin kalitesini mesleğe ilişkin bilgi ve becerinin verildiği ders programları, ders içerikleri, ders verme şekli ve araçları, öğretim elemanları ve öğrenciler belirleyecektir. Muhasebe eğitimi bir mesleki eğitim olup, bu eğitimden beklenen kişiye mesleğin gerektirdiği bilgi ve becerinin kazandırılmasıdır. $\mathrm{Bu}$ bilgi ve beceri ders programlarıyla öğrencilere kazandırılmaktadır ve muhasebe mesleğine ilişkin bilimsel yeterlilik hem ulusal hem de uluslararası standartlarda düzenlenmiștir. Ders programlarının bu bilimsel yeterlilik kriterlerini karşıllyor olması eğitim kalitesini ölçmede bir kriter olarak alınabilir.

TMS/TFRS'lere uyum sayesinde işletmeler ve bilgi kullanıcılarına geçmişe nazaran daha gerçekçi ve yararlı bilgiler sunulacağını söylemek yanlıș olmayacaktır. Dolayısıyla TMS/TFRS'lere uygun muhasebe bilgisi ülkemiz işletmeleri ve ekonomisi açısından büyük öneme sahiptir. Yakın gelecekte uygulayıcılar olarak iş dünyasında yer almayı hedefleyen üniversite öğrencilerinin TMS/TFRS bilgisi ve gerekliliği konusundaki algılarının ölçülmesi çalışmanın temel amacını oluşturmaktadır.

\section{Litaretür Özeti}

Çalışma konusu ile ilgili olarak muhasebe meslek mensuplarının TMS/TFRS'ler hakkındaki alg1 ve bilgi düzeylerinin tespit edilmesi, standartlardan beklentilerinin saptanması ve standartlar hakkındaki düşüncelerinin belirlenmesine yönelik literatürde birçok araştırma mevcut olmakla birlikte, ön lisans, lisans ve lisansüstü öğrencileri üzerinde çok fazla çalışma yapılmamıştır. Konu ile ilgili literatür incelemesinde üniversite öğrencileri üzerinde yapılan çalışmalardan bazılarına kısaca aşağıda yer verilmiş̧tir.

Demirkutlu (2014), araştırmasında Gazi Üniversitesi işletme lisans öğrencileri üzerinde yaptığı çalışmada muhasebeye ilgisi yüksek olan öğrencilerle, bu alana ilgisi düşük veya orta seviyede olan öğrenciler arasında TMS/TFRS farkındalıkları açısından anlamlı bir farklılık tespit etmiştir. Birinci öğretim ile ikinci öğretim öğrencileri; muhasebe alanında staj yapan veya iş tecrübesi olan öğrencilerle olmayan öğrenciler arasında TMS/TFRS farkındalıkları açısından anlamlı bir farklılık saptamamıştır. İşletme son sınıf öğrencilerinin genel olarak TMS/TFRS konularında farkındalık sahibi olmadıkları görülürken, öğrencilerin öğrenim gördükleri üniversite ile TMS/TFRS tanınırlıkları farkındalıkları ve teknik bilgileri açısından anlamlı bir farkın varlığ 1 tespit edilmiştir.

Ülkü ve Gökgöz (2013), çalışmalarında Yalova Üniversitesi İktisadi ve İdari Bilimler Fakültesi (İ̈BF) işletme bölümü öğrencileri ile Yalova Meslek Yüksek Okulu (MYO) muhasebe ve vergi bölümü öğrencilerinin Uluslararası Finansal Raporlama Standartları (UFRS) farkındalık ve algı düzeylerini araştırmış ve öğrencilerin çoğunun standartları hiç duymadıklarını ve konu hakkında eğitim almadıklarını belirlemişlerdir. Öğrencilerin önemli bir çoğunluğunun standart bilgisine sahip olmanın yaşanılan yerde veya gelecek iş yaşamında faydası olacağını düşünmekte oldukları ve okulda UFRS veya Uluslararası Muhasebe Standartları (UMS) ile ilgili bir dersin olması durumunda seçmek istedikleri tespit edilmiştir.

Yıldız ve Yanık (2013), çalışmasında Kocaeli Üniversitesi İİF İşletme Bölümü 3. ve 4. sınıf öğrencilerinin TMS hakkındaki algılarını ortaya koymaya çalışmıştır. Muhasebe mesleğine ilgisi yüksek olan öğrenciler ile düşük olan öğrenciler arasında; muhasebe alanında çalışmayı düşünenler ve düşünmeyenlerin algıları arasında anlamlı bir fark ortaya çıkmış, diğer faktörlerde ise anlamlı bir fark çıkmamıştır.

Yanık vd.(2013), çalışmasında Kocaeli Üniversitesi'ne bağlı MYO'larda Muhasebe ve Vergi Uygulamaları programlarında öğrenim gören öğrencilerin TMS hakkındaki algılarını ortaya koymaya çalışmıştır. Muhasebe mesleğini mezuniyetten sonra icra etmeyi düşünen öğrencilerle, düşünmeyen öğrenciler, muhasebe mesleğine ilgi düzeyi yüksek olan öğrenciler ile düşük olan öğrenciler, staj ve iş tecrübesi olan öğrenciler ile olmayan öğrenciler, son sınıfta okuyan öğrenciler ile birinci sinıfta okuyan öğrenciler arasında muhasebe standartlarını algılamaları bakımından anlamlı farklar ortaya çıkmıştır. Ticaret meslek lisesi mezunu öğrenciler ile diğer liselerden mezun olan öğrenciler ve bölümü ilk sırada tercih eden öğrenciler ile 2 . ve diğer sirada tercih eden öğrenciler arasında muhasebe standartlarını algılamaları bakımından anlamlı farklar ortaya çıkmamıştır.

Kurnaz (2012), Dumlupınar Üniversitesi’nde okumakta olan öğrencilerden 451'inin katılımıyla bir anket çalışması gerçekleştirmiştir. Öğrencilerin TMS ve TFRS hakkındaki farkındalıklarını etkileyen faktörlerin tespit etmeye yönelik çalışmasında öğrencilerin muhasebe mesleğine yönelik ilgilerinin çok yüksek olduğunu belirttikleri ve TMS/TFRS'lerden bilgisi olan öğrencilerin öncelikle ticaret meslek lisesi mezunu öğrenciler olduklarının tespit edildiği belirtilmiştir. Çalışmada İIBF'de muhasebe bölümü dışında okuyan öğrencilerin muhasebe standartları hakkındaki farkındalık düzeyinin muhasebe bölümünde okuyan öğrencilerden düşük olduğu ortaya çıkmıştır. Ayrıca staj deneyimi olan, mesleğe ilgisinin yüksek olduğunu belirten öğrencilerin TMS/TFRS'ler hakkında bilgi sahibi olma konusunda diğer öğrencilere göre istatistiki olarak farklılaştıkları tespit edilmiştir.

Albu ve vd. (2012) çalışmalarında Romanya Bucharest Üniversitesi'nde muhasebe ve yönetim bilgi sistemleri fakültesinde okumakta olan 119 öğrenci üzerinde bir anket 
çalıșması gerçekleștirmișlerdir. Öğrencilerin ilke bazlı yaklaşımlı UFRS eğitimindeki zorluklar nedeniyle muhasebeyi mantık temelli ve karmaşık kurallar bütünü olarak algıladıkları belirtilmektedir. Bununla birlikte Romanya IFRS eğitiminde IFRS'nin önemine yeterince güçlü bir etki yaratamadığ

Patro ve Gupta'nin (2012) çalışmasında Hindistan'daki muhasebe müfredatında UFRS'lere adapte edilebilirliğ üzerine 90 MBA öğrencisine yaptığı anket sonucunda UFRS müfredatına ülkede acil ihtiyaç olduğunun tespit edildiği belirtilmiştir. Çoğu Hintli işletme öğrencisinin UFRS'lerden habersiz olduğu belirtilmiştir. Ankete katılan öğrencilerin yaş grupları ya da okudukları yıl grupları değişkenlerine göre istatistiki açıdan farklılık tespit edilememiștir. Kadın ve erkek öğrenciler arasında UFRS bilgileri hakkında aralarında fark tespit edildiği belirtilmiștir. Öğrencilerin UFRS'ler ile ilgili ders almaya daha istekli oldukları sonucuna ulaşılmıştır.

Aktaş, (2012) çalışmasında ülkemizdeki 97 devlet üniversitesinde 75 fakültedeki işletme bölümleri ile 53 vakıf üniversitesindeki 40 işletme bölümü ders programları incelenmiştir. Muhasebe standartlarına ilişkin ders verilen devlet ve vakıf üniversitelerinin sadece \% 4'ünde muhasebe standartları dersinin zorunlu ders olduğu, devlet üniversitelerinin \% 24'ünde, vakıf üniversitelerinin ise \% 19'unda seçmeli ders olduğu tespit edilmiştir. Muhasebe standartlarına ilişkin ayrı bir dersin ders programlarında yer almamasının bu bölümlerdeki öğrencilere bilgilendirme yapılmadığı anlamına gelmediği belirtilmekle birlikte bu durumun tamamen öğretim elemanının inisiyatifinde olduğu da belirtilmektedir.

Dağlar ve vd. (2011), çalışmasında Mehmet Akif Ersoy Üniversitesi'ne bağlı meslek yüksekokullarında öğrenim gören muhasebe ve vergi uygulamaları programı öğrencilerine TMS hakkındaki farkındalık ve düzeylerini ölçen sorular sormuşlardır. Özellikle muhasebe mesleğine ilgisi yüksek olan ve mezun olduktan sonra muhasebecilik yapmayı düşünen öğrencilerin muhasebe standartları hakkındaki farkındalıklarının diğerlerine göre daha yüksek olduğu tespit edilmiştir.

James ve Blaszczynski (2010), muhasebe öğrencilerinin UFRSalgısı konusunda bir çalışma yapmışlardır. Çalışmada yazarlar, öğrencilerin yarısının ABD'nin ülke olarak hazırlayıp uygulamaya geçirdiği kendi muhasebe standartları (US GAAP) ve UFRS'yi ABD'de finansal raporlama standard 1 olarak gördüklerini, öğrencilerin büyük bir çoğunluğu ise (\%72) sadece UFRS'yi finansal raporlama standardı olarak gördüklerini ortaya koymuşlardır. Ayrıca bu çalışmada, muhasebe eğitimi almayan öğrencilerin, muhasebe eğitimi alan öğrencilere göre US GAAP'i finansal raporlamada küresel raporlama standardı olarak daha fazla kabul ettikleri sonucuna ulaşılmıştır.

Poria (2009), Hindistan'da yaptığı araştırma ile UFRS/UMS'nın benimsenme ve uygulanma sürecinde karşılaşılan en önemli sorunları tespit etmeye çalışmış ve standartlara ilişkin eğitim sorunu ile bilgi kullanıcılarının söz konusu uluslararası uygulamaların etkisine yönelik farkındalık eksikliğinin en önemli sorunlar olduğunu tespit etmiştir.

\section{Araştırmanın Amacı}

Bu çalışmanın amac1, üniversite eğitim gören ön lisans ve lisans öğrencilerinin Türkiye Muhasebe ve Finansal
Raporlama Standartları konusunda belirlenen değişkenler (yaş, bölüm, sınıf ve staj yapmış olma) açısından aralarında farklılık olup olmadığını belirlemektir. Ayrıca öğrencilerin verdikleri cevaplara göre üniversite eğitimleri sırasında aldıkları TMS ve TFRS eğitimi hakkında durum tespiti yapmaktır.

\section{Araştırmanın Önemi}

TMS ve TFRS'nin ülkemiz işletmelerinde uygulamaya geçiş sürecinde üniversitelerde özellikle muhasebe derslerinin ağırlıklı olduğu ön lisans, lisans ve lisansüstü eğitim programlarında verilen muhasebe eğitiminin de bu zorunluluğa ayak uydurması gerekliliği doğmuştur. Birçok üniversite müfredat programlarına TMS/TFRS konularını eklemeye başlayarak öğrencilere bu konular hakkında teorik olarak bilgilendirmeye çalışmışlardır. Bu çalışma ile henüz yeni kurulmuş üniversiteler grubunda olan Bilecik Şeyh Edebali Üniversitesi'nde muhasebe eğitimi alan bölüm ve program öğrencilerinin Türkiye Muhasebe ve Finansal Raporlama Standartları hakkındaki bilgi ve algı düzeyleri tespit edilmeye çalışılacaktır.

\section{Araştırmanın Kapsamı ve Sınırlılıkları}

$\mathrm{Bu}$ çalışmanın örneklemini Bilecik Şeyh Edebali Üniversitesi İktisadi ve İdari Bilimler Fakültesi İşletme Bölümü ikinci, üçüncü ve dördüncü sınıf öğrencileri, Uygulamalı Bilimler Yüksekokulu (UBY) Muhasebe ve Denetim Bölümü ile Turizm İşletmeciliği ve Otelcilik bölümleri ikinci sınıf öğrencileri ve Üniversite'nin Meslek Yüksekokullarında Muhasebe ve Vergi Uygulamaları (MUVU) programlarında okumakta olan ikinci sınıf öğrencileri oluşturmaktadır.

$\mathrm{Bu}$ çerçevede 2015- 2016 güz döneminde yukarıda belirtilen bölüm ve programlara kayıtlı toplam öğrenci sayısı 893'tür. Örneklem büyüklüğünün belirlenmesinde basit tesadüfî örnekleme yöntemi formülü (Nakip, 2003: 212-214) kullanılmış ve \% 95 güven düzeyinde ve $\pm \% 5$ sapma aralığında önerilen örneklem büyüklüğü olarak 269 öğrenci ile anket yapılması gerektiği hesaplanmıştır. Toplamda 370 anket toplanmış olup, 367'si değerlendirmeye uygun görülmüştür. \% 95 güven düzeyinde toplanması gereken örnek büyüklüğünün tamamına ulaşılmıştır.

İşletme bölümüne kayıtlı toplam öğrenci sayısı 684 olup, 249 öğrenciye ulaşılmıştır. Uygulamalı bilimlerde kayıtlı öğrenci sayısı 73 olup, 38 tanesine ve MYO Muhasebe ve Vergi Uygulamaları Programları ikinci sinıflara kayıtlı 136 öğrenciden 80 tanesine ulaşılmıştır. Çalışma 2015-2016 güz döneminde yukarıda belirtilen bölümler ve program öğrencileri ile sınırlıdır. Güz dönemi olması ve 1.sınıf öğrencilerinin muhasebe derslerini yeni almaya başlamaları nedeniyle 1. Sınıf öğrencileri kapsama dâhil edilmemiştir.

\section{Araştırmanın Yöntemi}

$\mathrm{Bu}$ çalışmada anket yöntemi kullanılmış olup, araştırmacılar tarafindan hazırlanan anket metninin sadece iki bölümü bu çalışmada kullanılmıştır. Birinci bölümde öğrencilerin demografik özellikleri ile ilgili 10 soru, ikinci bölümde TMS/TFRS hakkındaki görüşlerini tespit etmeye yönelik 5'li Likert (5. Kesinlikle katılıyorum, 4.Katılıyorum, 3. Fikrim Yok, 2. Katılmıyorum, 1. Kesinlikle Katılmıyorum) ile ölçülen 25 soru sorulmuştur. Veriler IBM SPSS 21 Programı kullanılarak değerlendirilmiştir.

7.Araştırmanın Güvenilirlik Düzeyi 
Çalıșmada Cronbach's Alpha 0,822 olarak hesaplanmış olup, istatistiki açıdan yeterli bir değerdir.

Güvenilirlik analizinde kullanılan ölçüt, her bir değişken ve soru havuzunun toplamı için hesaplanan Cronbach Alpha değeridir. Bu değer "0" ile " 1 ” arasında değişmektedir. Alpha değeri 0,60 ile 0,80 arasında olduğunda güvenilirliğin iyi; 0,80 ile 1,00 arasında olduğunda ise güvenilirliğin yüksek olduğu belirtilmektedir (Kozak, 2014: 146).

\section{Araştırmada Test Edilen Hipotezler}

H1: TMS/TFRS'leri algılama düzeyleri konusunda öğrencilerin yaşları arasında istatistikî olarak anlamlı bir farklılık vardır.

Ön lisans veya lisans eğitimine yeni başlamıș öğrencilerin yaşları ile son sınıfa gelmiş öğrencilerin yaşları farklı olacağından, aradan geçen sürede öğrencilerin okudukları dersler açısından aldıkları eğitim düzeylerinde de farklılık olacaktır. $\mathrm{Bu}$ da öğrencilerin yaş farkı sebebiyle TMS/TFRS'ler hakkındaki algı düzeylerinin farklı olmasına neden olacaktır. H1 hipotezi ile bu durum test edilmeye çalışılacaktır.

H2: TMS/TFRS'leri alg1lama düzeyleri konusunda öğrencilerin okudukları bölümler arasında istatistikî olarak anlamlı bir farklılık vardır.

Araştırmanın yapıldığı bölüm ve programlardaki müfredat programlarında muhasebe dersleri yer almakla birlikte, müfredat programlarındaki muhasebe derslerinin sayısı ve içeriği aynı değildir. Bu nedenle muhasebe dersleri içermekle birlikte aralarında sayı ve içerik yönünden farklar olan bu bölüm ve programlarda okuyan öğrencilerin aralarında TMS/TFRS'leri algılama düzeyleri açısından fark olması gerektiği düşünülmektedir. $\mathrm{H} 2$ hipotezi ile bu durum test edilecektir.

H3: TMS/TFRS'leri algılama düzeyleri konusunda öğrencilerin okuduğu sınıflar arasında istatistikî olarak anlamlı bir farklılık vardır.

Ön lisans ve lisans eğitimine başlamıș 1. sınıf öğrenciler ile son sınıfa gelmiș öğrenciler arasında TMS/TFRS'ler hakkındaki bilgi düzeyinin farklı olacağı üniversitelerdeki ilgili bölüm ders programlarının müfredatları açısından bakıldığında açıkça görülebilmektedir. H3 hipotezi ile bu durum test edilmeye çalışılacaktır

H4: TMS/TFRS'leri algılama düzeyleri konusunda öğrencilerin staj tecrübesi arasında istatistikî olarak anlamlı bir farklılık vardır.

Ön lisans ve lisans bölüm ve programlarında okuyan bazı öğrenciler muhasebe alanında staj yapmış ya da yapmaktadır. $\mathrm{Bu}$ durum staj görmüş öğrencilerle görememiş öğrenciler arasında TMS/TFRS'ler hakkındaki alg1 düzeylerinde farklılık yaratmaktadır. H4 hipotezi ile bu durum test edilmeye çalışılacaktır.

\section{Araștırmanın Frekans Sonuçarı}

Değerlendirmeye alınan 367 adet anket sonuçlarına göre öğrencilerin demografik özellikleri Tablo 1'de verilmiştir. Ankete katılan öğrencilerin bölümleri açısından bakıldığında öğrencilerin \% 67,8'i işletme bölümü öğrencileri oldukları, \% 5,7'si Muhasebe ve Denetim bölümü öğrencileri olduğu, \% 21,8'i Muhasebe Vergi ve Uygulamaları bölümü ve \% 4,6's1 Turizm İşletmeciliği ve Otelcilik bölümü öğrencileri oldukları görülmüştür. Öğrencilerin \% 55'i ikinci sınıf, \% 22,3’ü üçüncü sinıf, \% 22,6's1 ise dördüncü sınıf öğrencisi oldukları belirlenmiştir. Öğrencilerin \% $\quad 33,8^{\prime}$ 'inin staj tecrübesinin olduğu, \% 66,2'sinin ise, staj tecrübesi olmadığg 1 verdiği cevaplardan anlaşılmaktadır. Öğrencilerin \% 64'ü mesleği icra etmeyi düşündüğü, \% 35,7'si muhasebe alanında çalışmayı düşünmediğini belirttiği görülmüştür.

Tablo 2'ye bakıldığında öğrencilerin aldıkları muhasebe derslerinde az da olsa TMS/TFRS konularından bahsedilip bahsedilmediği sorusuna verilen cevaplarda öğrencilerin \% 76'sının bahsedildiği cevabı verirken, \% 24'ünün ise hayır cevabı vererek bahsedilmediğini belirttiği görülmektedir. Öğrencilere standartlarla ilgili olarak açılmış seçmeli bir ders alıp almadığı sorusuna da Öğrencilerin \% 88,6's1 hayır cevabı vererek seçmeli ders almadıklarını, \% 11,4'ü ise evet cevabı vererek seçmeli ders aldıklarını belirtmişlerdir. Öğrencilere standartlarla ilgili aldıkları ders saatinin yeterli olup olmadığı sorulduğunda ise \% 25,3'ü yeterli görürken \% 74'1'i de yetersiz gördüğünü belirtmiştir. 
Tablo 1: Araștırmaya Katılanların Demografik Özellikleri

\begin{tabular}{|c|c|c|c|c|c|}
\hline Cinsiyet & $\mathbf{F}$ & $\%$ & Yaş Dağılımı & $\mathbf{F}$ & $\%$ \\
\hline Kadın & 219 & 59,7 & 20 ve alt1 & 152 & 41,4 \\
\hline Toplam & 367 & 100,0 & Toplam & 367 & 100,0 \\
\hline İşletme & 249 & 67,8 & Düz Lise & 147 & 40,1 \\
\hline Muhasebe ve Denetim & 21 & 5,7 & Anadolu Lisesi & 54 & 14,7 \\
\hline Turizm İşletm.ve Otelcilik & 80 & 21,8 & Diğer Meslek Liseleri & 83 & 22,6 \\
\hline Toplam & 367 & 100,0 & Diğer & 17 & 4,6 \\
\hline & & & Toplam & 367 & 100,0 \\
\hline Sinıf Düzeyi & $\mathbf{F}$ & $\%$ & Staj Tecrübesi & $\mathbf{F}$ & $\%$ \\
\hline 2. Sinif & 202 & 55,0 & Evet & 124 & 33,8 \\
\hline 3.Sinif & 82 & 22,3 & Hayır & 243 & 66,2 \\
\hline Evet & 235 & 64,0 & Düşük & 90 & 24,5 \\
\hline Hayır & 131 & 35,7 & Orta & 217 & 59,1 \\
\hline Cevapsiz & 1 & 0,3 & Yüksek & 59 & 16,1 \\
\hline \multirow[t]{2}{*}{ Toplam } & 367 & 100,0 & Cevapsız & 1 & 0,3 \\
\hline & & & Toplam & 367 & 100,0 \\
\hline
\end{tabular}

Tablo 2: Araştırmaya Katılanların TMS/TFRS Dersleri İle İlgili Özellikleri

\begin{tabular}{|l|r|r|r|r|r|r|}
\hline & \multicolumn{2}{|c|}{$\begin{array}{c}\text { Alunan Derslerde Standartlardan } \\
\text { Bahsedilme Durumu }\end{array}$} & \multicolumn{2}{c|}{$\begin{array}{c}\text { TMS/TFRS Standartları Hakkında } \\
\text { Açlmıs Ayri Bir Seçmeli Ders Alma } \\
\text { Durumu }\end{array}$} & \multicolumn{2}{c|}{$\begin{array}{c}\text { Standartlarla Illgili Ders Saati } \\
\text { Yeterli mi? }\end{array}$} \\
\hline Cevap & F & $\%$ & F & \% & F & $\%$ \\
\hline Evet & 279 & 76,0 & 42 & 11,4 & 93 & 25,3 \\
\hline Hayır & 88 & 24,0 & 325 & 88,6 & 272 & 74,1 \\
\hline Cevapsiz & & & & & 2 & 0,5 \\
\hline Toplam & 367 & 100,0 & 367 & 100,0 & 367 & 100,0 \\
\hline
\end{tabular}

Tablo 3: Genel Frekans Analizi Sonuçları

\begin{tabular}{|c|c|c|c|c|c|c|}
\hline Genel Düsünceler & 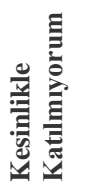 & 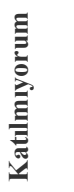 & $\begin{array}{l}\frac{4}{0} \\
\text { 吾 } \\
\text { 童 }\end{array}$ & 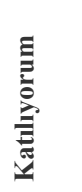 & 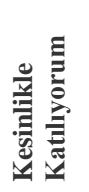 & 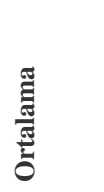 \\
\hline & 1 & 2 & 3 & 4 & 5 & \\
\hline $\begin{array}{l}\text { 1.Genel Muhasebe dersini almıs olan öğrenciler TMS/TFRS'yi kendi çabaları } \\
\text { ile ögrenebilir. }\end{array}$ & 51 & 117 & 103 & 87 & 9 & 2,69 \\
\hline $\begin{array}{l}\text { 2.Standartların karmaşık olması nedeniyle TMS/TFRS eğitimlerinin üniversite } \\
\text { eğitimi sırasında verilmesi tamamlanması mümkündeğildir. }\end{array}$ & 29 & 78 & 129 & 107 & 24 & 3,05 \\
\hline $\begin{array}{l}\text { 3.TMS/TFRS'ye göre hazırlanan mali tablolar işletmelerin durumunu, mevcut } \\
\text { geleneksel muhasebe uygulamalarna göre şeffaf bir biçimde ortaya koymayı } \\
\text { sağlamısıtır. }\end{array}$ & 10 & 28 & 175 & 120 & 34 & 3,38 \\
\hline 4.TMS/TFRS'ye göre hazırlanan mali tablolar daha ayrıntıll hale gelmiştir. & 14 & 30 & 157 & 133 & 33 & 3,38 \\
\hline $\begin{array}{l}\text { 5.TMS/TFRS'lerin iyi şekilde öğrenilmesinin muhasebe mesleğini icra } \\
\text { edenler/edecekler için oldukça gerekli olduğuna inanıyorum. }\end{array}$ & 36 & 31 & 103 & 128 & 69 & 3,44 \\
\hline $\begin{array}{l}\text { 6. TMS/TFRS Ĕ̈itimlerin TÜRMOB tarafindan meslek mensuplarına } \\
\text { verilmeye başlanması uygulama sürecinikolaylaştırmıștır. }\end{array}$ & 16 & 24 & 213 & 87 & 27 & 3,23 \\
\hline $\begin{array}{l}\text { 7.TMS/TFRS'ler ülkemizdeki muhasebe meslek mensuplarının mesleki } \\
\text { saygınlıklarıın gelişimine olumlu katkısağlamıştır. }\end{array}$ & 17 & 46 & 167 & 108 & 29 & 3,23 \\
\hline $\begin{array}{l}\text { 8.TMS/TFRS standartları ülkemizdeki muhasebe uygulamalarını dünya ile } \\
\text { oldukça uyumlu hale getirir. }\end{array}$ & 12 & 33 & 157 & 128 & 37 & 3,40 \\
\hline $\begin{array}{l}\text { 9.TMS/TFRS'ler muhasebe meslek mensuplarının dünyadaki diğer meslek } \\
\text { mensuplarıyla ortak bir dil konuşmalarını sağlamış̧ır. }\end{array}$ & 12 & 38 & 166 & 119 & 32 & 3,33 \\
\hline $\begin{array}{l}\text { 10.Ülkemizde Tekdüzen Muhasebe Sisteminin yeterli olduğunu ve } \\
\text { TMS/TFRS'nin uygulanmasına gerek olmadı̆ı̆ın düşünüyorum. }\end{array}$ & 49 & 76 & 167 & 60 & 15 & 2,77 \\
\hline $\begin{array}{l}\text { 11.TMS/TFRS'lerde çok fazla ayrıntı ve detaya inilmesi mali tabloların } \\
\text { hazırlanmasını güçleștirmektedir. }\end{array}$ & 23 & 45 & 174 & 89 & 36 & 3,19 \\
\hline
\end{tabular}




\begin{tabular}{|l|c|c|c|c|}
\hline $\begin{array}{l}\text { 12. TMS/TFRS eğitimlerinin Ticaret Meslek Liselerinde verilmesi daha doğru } \\
\text { olur. }\end{array}$ & 46 & 57 & 124 & 96 \\
\hline $\begin{array}{l}\text { 13.TMS/TFRS'lerin uygulanmasında mevcut muhasebe hesap planı yerine } \\
\text { başka bir hesap planı oluşturulmalıdır. }\end{array}$ & 28 & 55 & 216 & 55 \\
\hline
\end{tabular}

Tablo 3: Genel Frekans Analizi Sonuçları ( Devamı)

\begin{tabular}{|c|c|c|c|c|c|c|}
\hline$\underline{\text { Genel Düșünceler }}$ & 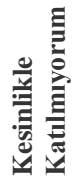 & 志 & 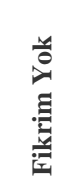 & 茙 & 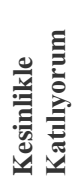 & 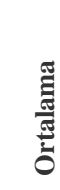 \\
\hline & 1 & 2 & 3 & 4 & 5 & \\
\hline $\begin{array}{l}\text { 14.TMS/TFRS eğitimi ilgili lisans ve önlisans programlarında ayrı bir ders } \\
\text { olarak açılarak verilmelidir. }\end{array}$ & 27 & 49 & 95 & 131 & 65 & 3,43 \\
\hline $\begin{array}{l}\text { 15. Ülkemizde TMS/TFRS standartlarından sorumlu olan kurumlar hakkında } \\
\text { oldukça bilgi sahibiyim. }\end{array}$ & 88 & 90 & 138 & 40 & 11 & 2,44 \\
\hline 16. Okuduğum bölümde TMS/TFRS dersleri zorunlu ders olarak verilmelidir. & 41 & 70 & 109 & 111 & 36 & 3,08 \\
\hline $\begin{array}{l}\text { 17. TMS/TFRS ile ilgili aldığım eğitimlerde üniversitedeki ders hocalarımı } \\
\text { yeterli buluyorum. }\end{array}$ & 54 & 80 & 122 & 79 & 32 & 2,88 \\
\hline 18. TMS/TFRS hakkında daha fazla teorik bilgi verilmesi gerekir. & 25 & 31 & 123 & 122 & 66 & 3,47 \\
\hline 19. TMS/TFRS hakkında daha fazla uygulama yapılması gerekir. & 27 & 28 & 117 & 117 & 78 & 3,52 \\
\hline $\begin{array}{l}\text { 20.TMS/TFRS uygulamalarının muhasebe paket programlarıyla birlikte } \\
\text { anlatılması gerekir. }\end{array}$ & 21 & 26 & 134 & 116 & 70 & 3,51 \\
\hline $\begin{array}{l}\text { 21.TMS/TFRS'ler VUK, TTK, KVK'lara göre muhasebe uygulamalarına daha } \\
\text { fazla esneklik getirmiştir. }\end{array}$ & 18 & 27 & 242 & 59 & 21 & 3,10 \\
\hline $\begin{array}{l}\text { 22.TMS/TFRS'ye göre hazırlanan finansal tabloların kalite düzeyi daha da } \\
\text { artmıştır. }\end{array}$ & 11 & 15 & 210 & 117 & 14 & 3,29 \\
\hline $\begin{array}{l}\text { 23. TMS/TFRS'ye göre hazırlanan mali tablolar, işletmelere stratejik ve önemli } \\
\text { kararların alınmasında doğru ve güvenilir finansal bilgi sunar. }\end{array}$ & 9 & 15 & 185 & 133 & 25 & 3,41 \\
\hline $\begin{array}{l}\text { 24. TMS/TFRS eğitiminin mesleği icra etmeyi seçen kişilere ilgili kurum ve } \\
\text { özel kuruluşlar aracilığıyla verilmesi dahadoğru olur. }\end{array}$ & 16 & 39 & 178 & 109 & 25 & 3.24 \\
\hline $\begin{array}{l}\text { 25.TMS/TFRS eğitiminin muhasebe stajina başlamış kişilere meslek odaları } \\
\text { aracillğıyla verilmesi daha doğru olur. }\end{array}$ & 12 & 42 & 145 & 135 & 33 & 3,37 \\
\hline
\end{tabular}

Öğrencilerin TMS/TFRS uygulamaları hakkındaki genel düşüncelerini ölçmek için 25 adet soru 5 'li Likert ölçeği kullanılarak sorulmuş ve cevaplamaları istenmiştir. Tablo 3 'teverilen cevaplar ve ortalama değerleri görülmektedir.

Ortalama değerlere göre incelendiğinde en yüksek AO değeri $(3,52)$ "TMS/TFRS hakkında daha fazla uygulama yapılması gerekir" ifadesi almıştır. Öğrenciler TMS/TFRS'ler hakkında derslerde daha fazla uygulama yapılması gerektiğine katıldıklarını belirtmişlerdir. Ayrıca "TMS/TFRS uygulamalarının muhasebe paket programlarıyla birlikte anlatılması gerekir" ifadesi $(3,51)$ ortalama sonucu ile ikinci en yüksek $\mathrm{AO}$ değerini almıştır. $\mathrm{Bu}$ sonuç ile öğrencilerin TMS/TFRS uygulamalarını paket programlarla anlatılması gerektiği düşüncesinde oldukları ortaya çıkmıştır.

En düşük AO değerlerinden ilki $(2,44)$ ile "Ülkemizde TMS/TFRS standartlarından sorumlu olan kurumlar hakkında oldukça bilgi sahibiyim" ifadesi almıştır. Bu sonuçla ögrencilerin muhasebe standartları ile ilgili kurumlar hakkında bilgi sahibi olmadıkları ortaya çıkmıştır. İkinci en düşük $\mathrm{AO}$ değeri sırasında $(2,69) \mathrm{AO}$ değeri ile "Genel Muhasebe dersini almış olan ögrenciler TMS/TFRS'yi kendi çabaları ile öğrenebilir" ifadesi bulunmuștur. Öğrenciler genel muhasebe derslerini alsalar bile TMS/TFRS'yi kendi çabalarıyla öğrenebileceklerini düşünmedikleri görülmüsştü.

\section{Araştırmanın Test Analizi Sonuçları}

Ankete verilen cevapların analizinde frekans, ortalama ve standart sapma değerlendirmeleriyle birlikte $\mathrm{t}$-testi ve Tek Yönlü Anova testi uygulanmıştır. Yaş değişkenine göre yapılan t-testi analizi sonucunda Tablo 4'te görülen ve aşağıda açıklanan 5 ifadede istatistiki olarak anlamlı fark $(\mathrm{P} \leq 0,05)$ tespit edilmiştir.

- "TMS/TFRS'ye göre hazırlanan mali tablolar işletmelerin durumunu, mevcut geleneksel muhasebe uygulamalarına göre şeffaf bir biçimde ortaya koymayı sağlamıştır" ifadesine verilen cevaplara göre 21 yaş ve üstü öğrenciler ve 20 yaş ve altındaki öğrenciler arasında istatistiki fark olduğu tespit edilmiștir. 
- "TMS/TFRS'lerde çok fazla ayrıntı ve detaya inilmesi mali tabloların hazırlanmasını güçleştirmektedir" ifadesine verilen cevaplara göre 21 yaş ve üstü öğrenciler ve 20 yaş ve altındaki öğrenciler arasında istatistiki fark olduğu tespit edilmiştir. Yaşça küçük olan öğrencilerin bu ifade için "fikrim yok" seçeneğini daha fazla işaretledikleri görülmektedir.

- "TMS/TFRS eğitimi ilgili lisans ve ön lisans programlarında ayrı bir ders olarak açılarak verilmelidir" ifadesine verilen cevaplara göre 21 yaş ve üstü öğrenciler ve 20 yaş ve altındaki öğrenciler arasında istatistiki fark olduğu tespit edilmiştir.

- "TMS/TFRS hakkında daha fazla uygulama yapılması gerekir" ifadesine verilen cevaplara göre 21 yaş ve üstü öğrenciler ve 20 yaş ve altındaki öğrenciler arasında istatistiki fark olduğu tespit edilmiştir.

- “TMS/TFRS'ye göre hazırlanan mali tablolar, işletmelere stratejik ve önemli kararların alınmasında doğru ve güvenilir finansal bilgi sunar" ifadesine verilen cevaplara göre 21 yaş ve üstü öğrenciler ve 20 yaş ve altındaki öğrenciler arasında istatistiki istatistiki fark olduğu tespit edilmiştir.

“H1: Öğrencilerin yaşları ile TMS/TFRS'leri algılama düzeyleri arasında istatistikî olarak anlamlı bir farklılık vardır" hipotezi yukarıda sayılan 5 ifade için kabul, diğer 20 ifade için reddedilmiştir.

Tablo 5'de öğrencilerin okudukları bölümler açısından aralarında istatistiki farklılık olup olmadığının tespiti için uygulanan One-Way ANOVA testi (Altunışık vd., 2007: 182183) sonuçları görülmektedir. Verilerin analizinde, grupların varyansları homojen özellik göstermediğinden dolayı Dunnett's T3 testi kullanılmıştır.

Tablo 5'teki 6 ifadede istatistiki anlamlı fark olduğu $(\mathrm{P} \leq 0,05)$ tespit edilen sonuçlar koyu punto ile gösterilmiştir. Öğrencilerin okudukları bölüm değişkeni açısından Anova analiziyle tespit edilen 6 ifadede hangi bölümler arasında istatistiki fark olduğunun tespiti için Dunnett T3 testi uygulanmıștır. Tablo 6'da hangi bölümler arasında istatistiki fark olduğuna dair sonuçlar gösterilmektedir.

Tablo 4: TMS/TFRS Hakkında Genel Düşüncelerini Ölçen İfadelerin Yaş Değişkenine Göre T-Test Analizi Sonuçları

\begin{tabular}{|c|c|c|c|c|c|c|c|c|}
\hline İfade & Yaş & $\mathbf{F}$ & AO & SS & $t$ & sd & $\begin{array}{c}\text { Sig. } \\
\text { Levene }\end{array}$ & $\begin{array}{c}\mathbf{P} \\
\text { T-Testi }\end{array}$ \\
\hline \multirow{2}{*}{$\begin{array}{l}\text { TMS/TFRS'ye göre hazırlanan mali } \\
\text { tablolar işletmelerin durumunu, mevcut } \\
\text { geleneksel muhasebe uygulamalarına göre } \\
\text { şeffaf bir biçimde ortaya koymayı } \\
\text { sağlamıștır. }\end{array}$} & 20 ve Alt 1 & 152 & 2,71 & 1,040 & $-2,860$ & 365 &, 030 &, 004 \\
\hline & $\begin{array}{l}21 \text { ve } \\
\text { Üstü }\end{array}$ & 215 & 2,67 & 1,070 & $-2,886$ & 335,166 & & ,004* \\
\hline \multirow{2}{*}{$\begin{array}{l}\text { TMS/TFRS'lerde çok fazla ayrıntı ve } \\
\text { detaya inilmesi mali tabloların } \\
\text { hazırlanmasını güçleştirmektedir. }\end{array}$} & 20 ve Alt 1 & 152 & 3,01 & 895 & $-3,039$ & 365 & ,000 & ,003 \\
\hline & $\begin{array}{l}21 \text { ve } \\
\text { Üstü }\end{array}$ & 215 & 3,32 & 1,030 & $-3,112$ & 349,700 & & ,002* \\
\hline \multirow{2}{*}{$\begin{array}{l}\text { TMS/TFRS eğitimi ilgili lisans ve ön } \\
\text { lisans programlarında ayrı bir ders olarak } \\
\text { açılarak verilmelidir. }\end{array}$} & 20 ve Alt1 & 152 & 3,24 & 1,185 & $-2,653$ & 365 &, 355 & ,008* \\
\hline & $\begin{array}{l}21 \text { ve } \\
\text { Üstü }\end{array}$ & 215 & 3,56 & 1,100 & $-2,620$ & 309,878 & & ,009 \\
\hline \multirow{2}{*}{$\begin{array}{l}\text { TMS/TFRS hakkında daha fazla } \\
\text { uygulama yapılması gerekir. }\end{array}$} & 20 ve Alt & 152 & 3,38 & 1,127 & $-1,991$ & 365 & ,817 & ,047* \\
\hline & $\begin{array}{l}21 \text { ve } \\
\text { Üstü }\end{array}$ & 215 & 3,62 & 1,121 & $-1,989$ & 319,369 & &, 048 \\
\hline \multirow{2}{*}{$\begin{array}{l}\text { TMS/TFRS'ye göre hazırlanan mali } \\
\text { tablolar, işletmelere stratejik ve önemli } \\
\text { kararları alınmasında doğru ve güvenilir } \\
\text { finansal bilgi sunar. }\end{array}$} & 20 ve Alt1 & 152 & 3,30 & ,764 & $-2,202$ & 365 & ,228 & ,028* \\
\hline & $\begin{array}{l}21 \text { ve } \\
\text { Üstü }\end{array}$ & 215 & 3,48 & ,784 & $-2,212$ & 330,514 & & ,028 \\
\hline
\end{tabular}

$*_{\mathrm{p}} \leq 0,05, \mathrm{~N}$ :Cevaplayan Sayıs1, AO:Aritmetik Ortalama, SS: Standart Sapma, Sd: Serbestlik Derecesi

Tablo 5: Öğrencilerin Bölümleri Açısından TMS/TFRS Hakkındaki Düşünceleri İçin One Way Anova Testi

\begin{tabular}{|c|c|c|c|c|}
\hline İfadeler & sd & Ortalama Kare & $\mathbf{F}$ & Sig. \\
\hline \multirow{2}{*}{$\begin{array}{l}\text { TMS/TFRS'ye göre hazırlanan mali tablolar işletmelerin durumunu, mevcut geleneksel } \\
\text { muhasebe uygulamalarına göre şeffaf bir biçimde ortaya koymayı sağlamıştır. }\end{array}$} & 2 & 4,743 & 6,611 & ,002 \\
\hline & 364 & ,717 & & \\
\hline \multirow{2}{*}{$\begin{array}{l}\text { Ülkemizde TMS/TFRS standartlarından sorumlu olan kurumlar hakkında oldukça bilgi } \\
\text { sahibiyim. }\end{array}$} & 2 & 11,011 & 10,262 & ,000 \\
\hline & 364 & 1,073 & & \\
\hline \multirow{2}{*}{ TMS/TFRS ile ilgili aldığım eğitimlerde üniversitedeki ders hocalarımı yeterli buluyorum. } & 2 & 7,109 & 5,355 &, 005 \\
\hline & 364 & 1,328 & & \\
\hline \multirow{2}{*}{ TMS/TFRS hakkında daha fazla uygulama yapılması gerekir. } & 2 & 8,052 & 6,521 &, 005 \\
\hline & 364 & 1,235 & & \\
\hline \multirow[t]{2}{*}{ TMS/TFRS hakkında daha fazla teorik bilgi verilmesi gerekir. } & 2 & 4,786 & 4,090 & ,018 \\
\hline & 364 & 1,170 & & \\
\hline \multirow{2}{*}{ TMS/TFRS uygulamalarının muhasebe paket programlarıyla birlikte anlatılması gerekir. } & 2 & 3,158 & 2,850 & ,059 \\
\hline & 364 & 1,108 & & \\
\hline
\end{tabular}
$* \mathrm{p} \leq 0,05$

- “TMS/TFRS'ye göre hazırlanan mali tablolar işletmelerin durumunu, mevcut geleneksel muhasebe uygulamalarına göre şeffaf bir biçimde ortaya koymayı sağlamıştır" ifadesinde İşletme bölümü öğrencileri ile Muhasebe ve
Vergi Uygulamaları öğrencileri arasında fark tespit edilmiş olup, fark işletme bölümü öğrencileri lehine,

- "Ülkemizde TMS/TFRS standartlarından sorumlu olan kurumlar hakkında oldukça bilgi sahibiyim" ifadesinde İşletme bölümü öğrencileri ile Muhasebe ve Vergi 
Uygulamaları öğrencileri arasında fark tespit edilmiş olup, fark Muhasebe ve Vergi Uygulamaları öğrencileri lehine,

- "TMS/TFRS ile ilgili aldığım eğitimlerde üniversitedeki ders hocalarımı yeterli buluyorum" ifadesinde İşletme bölümü öğrencileri ile Muhasebe ve Vergi Uygulamaları öğrencileri arasında fark tespit edilmiş olup, fark Muhasebe ve Vergi Uygulamaları öğrencileri lehine,

- "TMS/TFRS hakkında daha fazla uygulama yapılması gerekir." ifadesinde İşletme bölümü öğrencileri ile Muhasebe ve Vergi Uygulamaları öğrencileri arasında fark tespit edilmiş olup, fark Muhasebe ve Vergi Uygulamaları öğrencileri lehine, ayrıca; İşletme bölümü öğrencileri ile Uygulamalı Bilimler bölümü öğrencileri arasında fark tespit edilmiş olup, fark işletme bölümü öğrencileri lehine,
- "TMS/TFRS hakkında daha fazla teorik bilgi verilmesi gerekir" ifadesinde İşletme bölümü öğrencileri ile Muhasebe ve Vergi Uygulamaları öğrencileri arasında fark tespit edilmiş olup, fark işletme bölümü öğrencileri lehine fark olduğu tespit edilmiştir.

- "TMS/TFRS uygulamalarının muhasebe paket programlarıyla birlikte anlatılması gerekir" ifadesinde İşletme bölümü öğrencileri ile Muhasebe ve Vergi Uygulamaları öğrencileri arasında fark tespit edilmiş olup, fark işletme bölümü öğrencileri lehine fark olduğu tespit edilmiştir.

"H2: Öğrencilerin okudukları bölümler ile TMS/TFRS'leri algılama düzeyleri arasında istatistikî olarak anlamlı bir farklılık vardır" hipotezi Tablo 6'daki sayılan 6 ifade için kabul, Tablo 6'da gösterilmemiş olan diğer 19 ifade için reddedilmiştir.

Tablo 6: Öğrencilerin Bölümleri Açısından TMS/TFRS Hakkındaki Düşünceleri İçin Dunnett T3 Testi

\begin{tabular}{|c|c|c|c|c|c|}
\hline İfade & Bölümler & Bölümler & $\begin{array}{l}\text { Ortalama } \\
\text { Farkı }\end{array}$ & Std. Hata & $\mathbf{P}$ \\
\hline \multirow{6}{*}{$\begin{array}{l}\text { TMS/TFRS'ye göre hazırlanan mali tablolar işletmelerin } \\
\text { durumunu, mevcut geleneksel muhasebe uygulamalarına } \\
\text { göre şeffaf bir biçimde ortaya koymayı sağlamış̧ır. }\end{array}$} & \multirow{2}{*}{ İşletme } & UB &, 140 & , 148 &, 722 \\
\hline & & MVU &, $394^{*}$ & ,098 &, $000^{*}$ \\
\hline & \multirow{2}{*}{ UBY } & İşletme &,- 140 & ,148 &, 722 \\
\hline & & MVU &, 255 & ,159 & ,302 \\
\hline & \multirow{2}{*}{ MVU } & İşletme &,$- 394^{*}$ & ,098 &, $000^{*}$ \\
\hline & & UB &,- 255 & , 159 &, 302 \\
\hline \multirow{6}{*}{$\begin{array}{l}\text { Ülkemizde TMS/TFRS standartlarından sorumlu olan } \\
\text { kurumlar hakkında oldukça bilgi sahibiyim. }\end{array}$} & \multirow{2}{*}{ İşletme } & UB & ,433 & , 186 & ,069 \\
\hline & & MVU &,$- 560 *$ & , 146 &, $000 *$ \\
\hline & \multirow{2}{*}{ UBY } & İşletme & ,433 & , 186 & ,069 \\
\hline & & MVU &,- 127 & , 194 & ,885 \\
\hline & \multirow{2}{*}{ MVU } & İşletme &, $560 *$ & ,113 &, $000 *$ \\
\hline & & UB &, 127 & , 194 &, 885 \\
\hline \multirow{6}{*}{$\begin{array}{l}\text { TMS/TFRS ile ilgili aldığım eğitimlerde üniversitedeki ders } \\
\text { hocalarımı yeterli buluyorum. }\end{array}$} & \multirow{2}{*}{ İşletme } & UB &,$- 542 *$ & ,217 &, 046 \\
\hline & & MVU &,$- 341 *$ & ,127 &, $023^{*}$ \\
\hline & \multirow{2}{*}{ UBY } & İşletme &, $542 *$ & ,217 & ,046 \\
\hline & & MVU & ,202 & ,227 & ,754 \\
\hline & \multirow{2}{*}{ MVU } & İşletme &, $341 *$ & ,127 & ,023* \\
\hline & & UB &,- 202 & ,227 &, 754 \\
\hline \multirow{6}{*}{$\begin{array}{l}\text { TMS/TFRS hakkında daha fazla teorik bilgi verilmesi } \\
\text { gerekir. }\end{array}$} & \multirow{2}{*}{ İşletme } & UB &, 373 & ,219 & ,258 \\
\hline & & MVU &, $332 *$ & ,118 & ,017* \\
\hline & \multirow{2}{*}{ UBY } & İşletme &,- 372 & ,219 & ,258 \\
\hline & & MVU &,- 039 & ,228 & 997 \\
\hline & \multirow{2}{*}{ MVU } & İşletme &,$- 332 *$ & , 148 &, $017^{*}$ \\
\hline & & UB & ,039 &, 228 & ,997 \\
\hline \multirow{6}{*}{$\begin{array}{l}\text { TMS/TFRS hakkında daha fazla uygulama yapılması } \\
\text { gerekir. }\end{array}$} & \multirow{2}{*}{ İşletme } & UB &, $531 *$ & ,213 & 048* \\
\hline & & MVU &, $400 *$ & ,118 &, $003^{*}$ \\
\hline & \multirow{3}{*}{ UBY } & İşletme &,$- 531^{*}$ & ,213 &, $048 *$ \\
\hline & & MVU &,- 131 & ,220 & ,910 \\
\hline & & İşletme &,$- 400 *$ & ,118 & ,003* \\
\hline & MVU & UB & ,131 & ,220 & ,910 \\
\hline \multirow{5}{*}{$\begin{array}{l}\text { TMS/TFRS uygulamalarının muhasebe paket } \\
\text { programlarıyla birlikte anlatılması gerekir. }\end{array}$} & \multirow[t]{2}{*}{ İşletme } & UB & ,260 & , 192 & ,445 \\
\hline & & MVU & , $290^{*}$ & ,111 & ,028* \\
\hline & \multirow[t]{2}{*}{ UBY } & $\begin{array}{l}\text { Işletme } \\
\text { MVU }\end{array}$ & $\begin{array}{r}-, 260 \\
030\end{array}$ & , 192 & $\begin{array}{l}, 445 \\
.998\end{array}$ \\
\hline & & İşletme &,$- 290^{*}$ & 111 & ,028* \\
\hline & MVU & UB &,- 030 & 197 & 998 \\
\hline
\end{tabular}


Tablo 7: Öğrencilerin Okudukları Sınıflar Açısından TMS/TFRS Hakkına Genel Düşüncelerini Ölçen İfadeler İçin One Way Anova Testi

\begin{tabular}{|c|c|c|c|c|}
\hline İfadeler & sd & Ortalama Kare & $\mathbf{F}$ & Sig. \\
\hline \multirow{2}{*}{ TMS/TFRS'ye göre hazırlanan mali tablolar daha ayrıntılı hale gelmiştir. } & 2 & 4,235 & 5,346 & ,008 \\
\hline & 364 & ,792 & & \\
\hline \multirow{2}{*}{$\begin{array}{l}\text { TMS/TFRS Eğitimlerin TÜRMOB tarafından meslek mensuplarına verilmeye } \\
\text { başlanması uygulama sürecinikolaylaştırmıştır. }\end{array}$} & 2 & 2,499 & 3,522 & ,031 \\
\hline & 364 &, 710 & & \\
\hline \multirow{2}{*}{$\begin{array}{l}\text { TMS/TFRS'ler ülkemizdeki muhasebe meslek mensuplarının mesleki saygınlıklarının } \\
\text { gelişimine olumlu katkısağlamıştır. }\end{array}$} & 2 & 3,352 & 3,921 & ,021 \\
\hline & 364 &, 855 & & \\
\hline \multirow{2}{*}{$\begin{array}{l}\text { TMS/TFRS standartları ülkemizdeki muhasebe uygulamalarını dünya ile oldukça } \\
\text { uyumlu hale getirir. }\end{array}$} & 2 & 3,884 & 4,842 & ,008 \\
\hline & 364 &, 802 & & \\
\hline \multirow{2}{*}{$\begin{array}{l}\text { TMS/TFRS'lerde çok fazla ayrıntı ve detaya inilmesi mali tabloların hazırlanmasını } \\
\text { güçleştirmektedir. }\end{array}$} & 2 & 13,236 & 14,598 & ,000 \\
\hline & 364 &, 907 & & \\
\hline \multirow{2}{*}{$\begin{array}{l}\text { TMS/TFRS eğitimi ilgili lisans ve önlisans programlarında ayrı bir ders olarak } \\
\text { açılarak verilmelidir. }\end{array}$} & 2 & 5,984 & 4,654 & ,010 \\
\hline & 364 & 1,286 & & \\
\hline \multirow{2}{*}{$\begin{array}{l}\text { Ülkemizde TMS/TFRS standartlarından sorumlu olan kurumlar hakkında oldukça bilgi } \\
\text { sahibiyim. }\end{array}$} & 2 & 8,151 & 7,487 & ,001 \\
\hline & 364 & 1,089 & & \\
\hline \multirow{2}{*}{ Okuduğum bölümde TMS/TFRS dersleri zorunlu ders olarak verilmelidir. } & 2 & 8,313 & 6,441 & ,002 \\
\hline & 364 & 1,291 & & \\
\hline \multirow{2}{*}{ TMS/TFRS hakkında daha fazla teorik bilgi verilmesi gerekir. } & 2 & 5,879 & 5,050 & ,007 \\
\hline & 364 & 1,164 & & \\
\hline \multirow{2}{*}{ TMS/TFRS hakkında daha fazla uygulama yapılması gerekir. } & 2 & 8,087 & 6,550 & ,002 \\
\hline & 364 & 1,295 & & \\
\hline \multirow{2}{*}{$\begin{array}{l}\text { TMS/TFRS uygulamalarının muhasebe paket programlarıyla birlikte anlatılması } \\
\text { gerekir. }\end{array}$} & 2 & 4,506 & 4,093 & ,017 \\
\hline & 364 & 1,101 & & \\
\hline \multirow{2}{*}{ TMS/TFRS'ye göre hazırlanan finansal tabloların kalite düzeyi daha da artmıştır. } & 2 & 2,162 & 4,018 & ,019 \\
\hline & 364 &, 538 & & \\
\hline \multirow{2}{*}{$\begin{array}{l}\text { TMS/TFRS'ye göre hazırlanan mali tablolar, işletmelere stratejik ve önemli kararların } \\
\text { alınmasında doğru ve güvenilir finansal bilgi sunar. }\end{array}$} & 2 & 4,117 & 6,988 & ,001 \\
\hline & 364 &, 589 & & \\
\hline
\end{tabular}

$*_{\mathrm{p}} \leq 0,05$

Tablo 7'de öğrencilerin okudukları sınıflar açısından aralarında istatistiki fark olup olmadığının tespiti için Anova testi uygulanmıştır. Tablo 7'deki 13 ifadede istatistiki anlamlı fark olduğu $(\mathrm{P} \leq 0,05)$ tespit edilen sonuçlar koyu punto ile gösterilmiştir. Öğrencilerin sınıf değişkeni açısından Anova analiziyle tespit edilen 13 ifadede hangi gruplar arasında istatistiki fark olduğunun tespiti için Dunnett $\mathrm{T}$ testi uygulandığında bu 13 ifadeden sadece Tablo 8'de görülen 7 ifadede öğrencilerin okudukları sınıfları açısından aralarında istatistiki anlamlı farklılık olduğu tespit edilmiştir. Anlamlı değerler koyu punto ile gösterilmektedir.

- "TMS/TFRS'ye göre hazırlanan mali tablolar daha ayrıntılı hale gelmiştir." ifadesinde ikinci sınıf öğrencileri ile üçüncü sınıf öğrencileri arasında üçüncü sınıf öğrencileri lehine istatistiki fark çıkmıştır.

- "TMS/TFRS Eğitimlerin TÜRMOB tarafindan meslek mensuplarına verilmeye başlanması uygulama sürecinikolaylaştırmıştır." ifadesinde ikinci sınıf öğrencileri ile dördüncü sınıf öğrencileri arasında dördüncü sınıf öğrencileri lehine istatistiki fark çıkmıştır.

- “TMS/TFRS'ler ülkemizdeki muhasebe meslek mensuplarının mesleki saygınlıklarının gelişimine olumlu katkısağlamıştır." ifadesinde üçüncü sınıf öğrencileri ile dördüncü sınıf öğrencileri arasında dördüncü sınıf öğrencileri lehineistatistiki fark çıkmıştır.

- "TMS/TFRS standartları ülkemizdeki muhasebe uygulamalarını dünya ile oldukça uyumlu hale getirir." ifadesinde ikinci sınıf öğrencileri ile dördüncü sınıf öğrencileri arasında dördüncü sınıf öğrencileri lehineistatistiki fark çıkmıştır.

- "TMS/TFRS'lerde çok fazla ayrıntı ve detaya inilmesi mali tabloların hazırlanmasını güçleştirmektedir." ifadesinde ikinci sınıf öğrencileri ile üçüncü sınıf öğrencileri arasında fark tespit edilmiş olup, fark üçüncü sınıf öğrencileri lehine, ayrıca; ikinci sınıf öğrencileri ile dördüncü sınıf öğrencileri arasında dördüncü sınıf öğrencileri lehine istatistiki fark çıkmıştır.

- "TMS/TFRS eğitimi ilgili lisans ve ön lisans programlarında ayrı bir ders olarak açılarak verilmelidir." ifadesinde ikinci sınıf öğrencileri ile dördüncü sınıf öğrencileri arasında dördüncü sınıf öğrencileri lehine istatistiki fark çıkmıştır.

- "Ülkemizde TMS/TFRS standartlarından sorumlu olan kurumlar hakkında oldukça bilgi sahibiyim." ifadesinde ikinci sınıf öğrencileri ile üçüncü sınıf öğrencileri arasında fark tespit edilmiş olup, fark ikinci sınıf öğrencileri lehine, ayrıca; ikinci sınıf öğrencileri ile dördüncü sınıf öğrencileri arasında ikinci sınıf öğrencileri lehine istatistiki fark çıkmıştır. 
Tablo 8: Öğrencilerin Okudukları Sınıfları Açısından TMS/TFRS Hakkına Genel Düşüncelerini Ölçen İfadeler İçin Dunnett T3 Testi

\begin{tabular}{|c|c|c|c|c|c|}
\hline İfade & Sinıfı & Sinıfı & $\begin{array}{l}\text { Ortalama } \\
\text { Farkı }\end{array}$ & Std. Hata & $\mathbf{P}$ \\
\hline \multirow{6}{*}{$\begin{array}{l}\text { TMS/TFRS'ye göre hazırlanan mali tablolar daha ayrıntılı hale } \\
\text { gelmiştir. }\end{array}$} & \multirow{2}{*}{2} & 3 &,$- 357^{*}$ & , 104 & ,002* \\
\hline & & 4 &,- 229 & 130 & 223 \\
\hline & \multirow{2}{*}{3} & 2 &, $357^{*}$ & 104 &, $002 *$ \\
\hline & & 4 &, 128 & 143 &, 752 \\
\hline & \multirow{2}{*}{4} & 2 &, 229 & 130 & 223 \\
\hline & & 3 &,- 128 & 143 & 752 \\
\hline \multirow{6}{*}{$\begin{array}{l}\text { TMS/TFRS Eğitimlerin TÜRMOB tarafindan meslek mensuplarına } \\
\text { verilmeye başlanması uygulama sürecinikolaylaştırmıştır. }\end{array}$} & \multirow{2}{*}{2} & 3 &,- 037 & 116 & ,984 \\
\hline & & 4 &,$- 287 *$ & 109 &, $027 *$ \\
\hline & \multirow{2}{*}{3} & 2 & 0,37 & 116 & ,984 \\
\hline & & 4 &,- 251 & 137 &, 191 \\
\hline & \multirow[b]{2}{*}{4} & 2 & $287 *$ & 109 &, $027 *$ \\
\hline & & 3 & 251 & 137 &, 191 \\
\hline \multirow{6}{*}{$\begin{array}{l}\text { TMS/TFRS'ler ülkemizdeki muhasebe meslek mensuplarının } \\
\text { mesleki saygınlıklarının gelişimine olumlu katkısağlamıştır. }\end{array}$} & \multirow{2}{*}{2} & 3 &, 152 &, 124 &, 529 \\
\hline & & 4 &,- 245 & 119 &, 119 \\
\hline & \multirow{2}{*}{3} & 2 &,,- 152 & 124 &, 529 \\
\hline & & 4 &,$- 397 *$ & 146 &, $022 *$ \\
\hline & \multirow{2}{*}{4} & 2 &, 245 & 119 &, 119 \\
\hline & & 3 & ,397* &, 116 &, $022 *$ \\
\hline \multirow{6}{*}{$\begin{array}{l}\text { TMS/TFRS standartları ülkemizdeki muhasebe uygulamalarını } \\
\text { dünya ile oldukça uyumlu hale getirir. }\end{array}$} & \multirow{2}{*}{2} & 3 &,- 233 & 116 &, 134 \\
\hline & & 4 &,$- 335 *$ & 116 & ,013* \\
\hline & \multirow{2}{*}{3} & 2 &, 233 & 116 &, 134 \\
\hline & & 4 &,- 102 & 137 &, 838 \\
\hline & \multirow{2}{*}{4} & 2 & $335^{*}$ & 116 &, $013 *$ \\
\hline & & 3 &, 102 & 137 &, 838 \\
\hline \multirow{6}{*}{$\begin{array}{l}\text { TMS/TFRS'lerde çok fazla ayrıntı ve detaya inilmesi mali tabloların } \\
\text { hazırlanmasını güçleştirmektedir. }\end{array}$} & \multirow{2}{*}{2} & 3 &,$- 352 *$ & 137 & 034* \\
\hline & & 4 &,$- 649 *$ &, 118 &, $000 *$ \\
\hline & \multirow{2}{*}{3} & 2 &, $352 *$ & 137 &, $034 *$ \\
\hline & & 4 &,- 237 & 157 &, 169 \\
\hline & \multirow[t]{2}{*}{4} & 2 &, $649 *$ &, 118 &, $000 *$ \\
\hline & & 3 &, 297 & 157 &, 169 \\
\hline \multirow{6}{*}{$\begin{array}{l}\text { TMS/TFRS eğitimi ilgili lisans ve önlisans programlarında ayrı bir } \\
\text { ders olarak açılarak verilmelidir. }\end{array}$} & \multirow{3}{*}{2} & 3 &,- 367 & 155 &, 056 \\
\hline & & 4 &,$- 359^{*}$ & 143 &, $038 *$ \\
\hline & & 2 &, 367 & 155 & ,056 \\
\hline & \multirow[t]{2}{*}{3} & 4 & ,008 & 178 & 1,000 \\
\hline & & 2 &, $359^{*}$ & 143 &, $038 *$ \\
\hline & 4 & 3 &,- 008 & 178 & 1,000 \\
\hline \multirow{6}{*}{$\begin{array}{l}\text { Ülkemizde TMS/TFRS standartlarından sorumlu olan kurumlar } \\
\text { hakkında oldukça bilgi sahibiyim. }\end{array}$} & \multirow{3}{*}{2} & 3 & ,390* & 147 & ,026* \\
\hline & & 4 & $453 *$ & 140 &, $004 *$ \\
\hline & & 2 &,$- 390 *$ & 147 &, $026 *$ \\
\hline & 3 & 4 &, 063 & 179 & 979 \\
\hline & & 2 &,$- 453 *$ & 140 &, $004 *$ \\
\hline & 4 & 3 &,- 063 & , 179 & ,979 \\
\hline
\end{tabular}


Tablo 9: Öğrencilerin Staj Yapmaları Açısından TMS/TFRS Hakkına Genel Düşüncelerini Ölçen İfadeler İçin Independent Sample T-Test Analizi

\begin{tabular}{|c|c|c|c|c|c|c|c|c|}
\hline İfade & Cevap & $\mathbf{N}$ & AO & SS & $\mathrm{t}$ & Sd & $\begin{array}{c}\text { Sig. } \\
\text { Levene }\end{array}$ & $\begin{array}{c}\mathbf{P} \\
\text { T-Testi }\end{array}$ \\
\hline \multirow{2}{*}{$\begin{array}{l}\text { Genel Muhasebe dersini almış olan öğrenciler TMS/TFRS'yi } \\
\text { kendi çabaları ile ögrenebilir. }\end{array}$} & Evet & 124 & 2,90 & 1,081 & 2,688 & 365 & ,820 & ,008* \\
\hline & Hayır & 243 & 2,58 & 1,031 & 2,647 & $\begin{array}{r}237,6 \\
44 \\
\end{array}$ & & ,009 \\
\hline \multirow{2}{*}{$\begin{array}{l}\text { TMS/TFRS'lerin iyi şekilde öğrenilmesinin muhasebe } \\
\text { mesleğini icra edenler/edecekler için oldukça gerekli } \\
\text { olduğuna inaniyorum. }\end{array}$} & Evet & 124 & 3,60 & ,953 & 1,876 & 365 & ,000 & ,069 \\
\hline & Hayır & 243 & 3,36 & 1,270 & 2,055 & $\begin{array}{r}315,3 \\
44\end{array}$ & & ,041* \\
\hline \multirow[t]{2}{*}{$\begin{array}{l}\text { Ülkemizde TMS/TFRS standartlarından sorumlu olan } \\
\text { kurumlar hakkında oldukça bilgi sahibiyim. }\end{array}$} & Evet & 124 & 2,64 & ,974 & 2,505 & 365 & ,065 & ,013* \\
\hline & Hayır & 243 & 2,35 & 1,093 & 2,600 & $\begin{array}{r}274,2 \\
59 \\
\end{array}$ & & ,010 \\
\hline \multirow{2}{*}{$\begin{array}{l}\text { Okuduğum bölümde TMS/TFRS dersleri zorunlu ders olarak } \\
\text { verilmelidir. }\end{array}$} & Evet & 124 & 3,35 & 1,036 & 3,152 & 365 & , 125 & ,002* \\
\hline & Hayır & 243 & 2,95 & 1,118 & 3,294 & $\begin{array}{r}279,3 \\
74 \\
\end{array}$ & & ,001 \\
\hline \multirow{2}{*}{$\begin{array}{l}\text { TMS/TFRS'ye göre hazırlanan finansal tabloların kalite } \\
\text { düzeyi daha da artmıştır. }\end{array}$} & Evet & 124 & 3,44 & ,735 & 2,634 & 365 & ,097 &, $009 *$ \\
\hline & Hayır & 243 & 3,22 & ,733 & 2,631 & $\begin{array}{r}247,0 \\
92 \\
\end{array}$ & & ,009 \\
\hline
\end{tabular}

${ }^{*} \mathrm{p} \leq 0,05, \mathrm{~N}:$ Cevaplayan Sayıs1, AO:Aritmetik Ortalama, SS: Standart Sapma, Sd: Serbestlik Derecesi

“H3: Öğrencilerin okuduğu sinıfla TMS/TFRS'leri algılama düzeyleri arasında istatistikî olarak anlamlı bir farklılık vardır" hipotezi Tablo 7 ve Tablo 8'deki sonuçlara göre, Tablo 8'de listelenmiş 7 ifade için kabul, diğer 18 ifade için reddedilmiştir.

Öğrencilerin staj yapmış olma özellikleriaçısından verdikleri cevaplar arasında istatistiki fark olup olmadığının tespiti için uygulanan Independent Sample t-testi analizi sonucunda Tablo 9'da görülen 5 ifadede istatistiki anlamlı fark $(\mathrm{P} \leq 0,05)$ tespit edilmiștir. Anlamlı fark sonuçları tabloda koyu punto ve $(*)$ ile birlikte gösterilmiştir.

"Genel Muhasebe dersini almış olan öğrenciler TMS/TFRS'yi kendi çabaları ile öğrenebilir" ifadesinde staj yapan öğrencilerin lehine istatistiki fark olduğu tespit edilmiștir. AO açısından değerlendirdiğimizde ise staj yapan öğrencilerin bu ifade için daha çok "fikrim yok" seçeneğini işaretledikleri görülmektedir.

"TMS/TFRS'lerin iyi şekilde öğrenilmesinin muhasebe mesleğini icra edenler/edecekler için oldukça gerekli olduğuna inanıyorum" ifadesinde staj yapmamış olan öğrenciler lehine istatistiki fark olduğu tespit edilmiştir. AO açısından değerlendirildiğinde ise bu ifadeye staj yapmamış olan öğrencilerin daha çok "fikrim yok" seçeneğini işaretledikleri görülmektedir.

"Ülkemizde TMS/TFRS standartlarından sorumlu olan kurumlar hakkında oldukça bilgi sahibiyim" ifadesinde staj yapan öğrenciler lehine istatistiki fark olduğu tespit edilmiştir.

"Okuduğum bölümde TMS/TFRS dersleri zorunlu ders olarak verilmelidir" ifadesinde staj yapan öğrenciler lehine istatistiki fark olduğu tespit edilmiştir.

"TMS/TFRS' ye göre hazırlanan finansal tabloların kalite düzeyi daha da artmıştı"” ifadesinde staj yapan öğrenciler lehine istatistiki fark olduğu tespit edilmiştir. Staj yaptığını belirten öğrencilerin bu ifadeye daha çok katıldıkları tespit edilmiştir.
"H4: Öğrencilerin staj tecrübeleri açısından TMS/TFRS'leri algılama düzeyleri arasında istatistikî olarak anlamlı bir farklılık vardır" hipotezinde Tablo 9'daki sonuçlara göre 5 ifade için kabul diğer 20 ifade için ise reddedilmiștir.

\section{Sonuç}

Türkiye'de son y1llarda muhasebe standartları uygulamaları yetkili kurumlar, işletmeler ve muhasebe meslek mensupları açısından ilerleme kaydetmekle birlikte muhasebe standartlarının eğitimi açısından meslekle ilgili bölüm ve programlarda istenilen düzeye henüz gelinememiştir. Üniversitelerde ilgili bölümlerin müfredat programlarına konu ile ilgili dersler eklenmeye çalışılmaktadır. Özellikle devlet ve vakıf üniversitelerinde ilgili yüksek lisans ve doktora programlarında dersler yer almakla birlikte, ön lisans ve lisans programlarında TMS/TFRS'ler açısından yeterli bir gelişme sağlanamamıştır. Üniversite öğrencilerinin standartlarla ilgili bilgi ve eğitim düzeylerini belirlemeye yönelik olarak ülkemizde yapılmış araştırmalarda da öğrencilerin büyük çoğunluğunun TMS/TFRS hakkında yeterli bilgi sahibi olmadıklarının tespit edildiği görülmektedir. TMS/TFRS'lerin karmaşık ve zor olması verilen eğitimlerin yeterli gelmemesini etkilemektedir.

Çalışmada muhasebe derslerini daha fazla gören MYO, uygulamalı bilimler ve işletme bölümleri açısından TMS/TFRS eğitiminin öğrenciler açısından durumunun tespit edilmesi ve öğrencilerin algı düzeyleri açısından farklılık olup olmadığının tespiti amaçlanmıştır.

Çalı̧̧mada öğrencilere aldıkları muhasebe derslerinde az da olsa TMS/TFRS konularından bahsedilip bahsedilmediği sorusuna öğrencilerin yaklaşı $\% 75^{\prime} \mathrm{i}$ evet cevabını vermişlerdir. İşletme bölümü öğrencilerinin çoğunluğu ve MYO öğrencilerinin yarıdan fazlasının bu sorumuza evet cevabı verdikleri tespit edilmiştir. Seçmeli ders olarak TMS/TFRS konulu bir ders aldığını belirten öğrenciler az sayıda olmakla birlikte işletme bölümünde çıkmışıtır. Öğrencilerin çoğunluğunun standartlarla ilgili aldıkları ders saatinin yeterli olmadığını düşündükleri tespit edilmişsir. 
Öğrencilerin TMS/TFRS uygulamaları hakkındaki genel düşüncelerini ölçmek için sorduğumuz ifadelerden en yüksek katılım alan ifade "TMS/TFRS hakkında daha fazla uygulama yapılması gerekir" ifadesi olmuştur. Öğrenciler derslerde daha fazla uygulamalı TMS/TFRS konuları görmek istemektedirler. Ayrıca "TMS/TFRS uygulamalarının muhasebe paket programlarıyla birlikte anlatılması gerektiği belirtilmiştir. En düşük AO değerini "Ülkemizde TMS/TFRS standartlarından sorumlu olan kurumlar hakkında oldukça bilgi sahibiyim" ifadesi almıștır. Öğrencilerin muhasebe standartları ile ilgili kurumlar hakkında bilgi sahibi olmadıkları ortaya çıkmıştır. Ayrıca öğrencilerin Genel Muhasebe dersini almış olsalar bile TMS/TFRS'yi kendi çabaları ile öğrenebileceklerini düşünmedikleri ortaya çıkmıştır.

Yaş değiş̧keni açısından 20 yaş ve altı ile 21 yaş ve üstü öğrenciler arasında; uygulamalı bilimler, işletme, muhasebe ve vergi uygulamaları bölümleri arasında; 2.,3., ve 4. Sinıflar arasında; staj yapmış ve yapmamış öğrenciler arasında TMS/TFRS konularında istatistiki anlamlı farklılıklar olduğu tespit edilmiştir.

Sonuç olarak; ön lisans ve lisans düzeyindeki üniversite öğrencilerinin TMS/TFRS konusunda bilgi ve eğitim bakımından yetersiz olduğu söylenebilir. $\mathrm{Bu}$ bağlamda, okullarda TMS/TFRS ile ilgili olarak gerek dersin öğretim elemanları tarafından gerekse konu uzmanları çağrılarak seminer, konferans vb. etkinlikler ile öğrenciler bilgilendirilmelidir. Bunun yanında meslekle ilgili bölüm ve programlarda okutulan zorunlu muhasebe derslerinin TMS/TFRS'yi içerecek şekilde güncellenmesi veya TMS/TFRS'nin ayrı bir ders olarak seçmeli dersler arasına eklenmesi gerekmektedir.

\section{Kaynaklar}

Albu, N., Albu, C.N. ve Gîrbină, M.M. (2012), "Educating Accounting Students in an Emerging Economy - an Analysis of the Importantance of Stereotypes in Teaching IFRS". International Journal of Academic Research. 4(3), 51-57, May.

Altunışık, R., Coşkun, R., Bayraktaroğlu, S. ve Yıldırım E. (2007), Sosyal Bilimlerde Araştırma Yöntemleri SPSS Uygulamalı, 5. Bask1, Sakarya Yayıncılık, Sakarya.

Aktaş, R. ve Karğın M. (2012), "UFRS'ye Geçiș Sürecinde Yükseköğretimde Muhasebe Eğitiminin Değerlendirilmesi”, World of UFRS Dergisi, Aralı, http://dergi.mumeyek.org/pdfler/d1863.pdf, (Son Erişim Tarihi: 24 Ocak 2016)

Dalğar, H., Çelik, İ. ve Mortaş, M. (2011). "Muhasebe Öğrenimi Gören Öğrencilerin TMS/TFRS Hakkındaki Farkındalıklarına Yönelik Bir Araştırma", Süleyman Demirel Üniversitesi İIBF Dergisi. 6: 217-230.

Demirkutlu (Karakaya), F. (2014), “İşletme Lisans Öğrencilerinin Türkiye Muhasebe/Finansal Raporlama Standartları Hakkındaki İlgi Düzeyleri, Beklentileri ve Farkındalıkları: Gazi Üniversitesi İktisadi ve İdari Bilimler Fakültesi Örneği'" Gazi Üniversitesi İktisadi ve İdari Bilimler Dergisi. 2/16, 156-174.

James, M. L. ve Blaszczynski, C. (2010), “Accounting Students' Perceptions Of International Financial Reporting Standards", Journal for Global Business Education,. 10, 37-49.

Kozak, M. (2014), Bilimsel Araştırma: Yasarım, Yazım ve Yayım Teknikleri, Detay Yayıncılık, Ankara.
Kurnaz, N. (2002), "Statistical Analysis of the Factors Affecting Accounting Students' Awareness of the TAS (Turkish Accounting Standards) and TFRS (Turkish Financial Reporting Standards)",

http://www.ajournal.co.uk/pdfs/BSvolume4\%281\%29/BSVol.4\%20 \%281\%29\%20Article\%2014.pdf, (Son Erişim Tarihi:24 Ocak 2016).

James, M.L. ve Blaszczynski, C. (2010), “Accounting Students' Perceptions of international Financial Reporting Standarts", Journal for Global Business Education, 10, 37-49.

Nakip, M. (2003), Pazarlama Araştırmaları Teknikler ve SPSS Destekli Uygulamalar, Seçkin Yayıncılık, Ankara.

Poria, S. V. (2009), "IFRS Implementation and Challenges in India" Maharashtra Economic Development Council-MEDC Monthly Economic Digest (August).

Ülkü, S. ve Gökgöz, A. (2013), “Lisans ve Ön Lisans Düzeyinde Öğrenim Gören Öğrencilerin Türkiye Muhasebe ve Finansal Raporlama Standartları Konusundaki Bilgi ve Alg1 düzeylerinin ve Farkındalıklarının Ölçülmesi: Yalova Örneğii" Mali Çözüm Dergisi, 12(116), (Mart-Nisan): 39-56

Yanık, A., Yıldız, F., Kara, E. Ve Günce, N. (2013), "Muhasebe Eğitimi Gören Ön lisans Öğrencilerinin Muhasebe Standartları Hakkındaki Algıları Üzerine Bir Araştırma", Dumlupınar Üniversitesi Sosyal Bilimler Dergisi. 36, 243-252, Nisan.

Yıldız, F. ve Yanık, A. (2013), "Yüksek Öğretimde Öğrenim Gören Öğrencilerin Muhasebe ve Finansal Raporlama Standartları Hakkındaki Algıları: Ampirik Çalışma', Süleyman Demirel Üniversitesi Sosyal Bilimler Enstitüsü Dergisi, 1(17), 205-220.

Yılmaz, Z., Şahin, Z. ve Çankaya, F. (2014), “Orta ve Doğu Karadeniz Bölgesindeki Öğrenci, Akademisyen ve Uygulayıcıların TMS/TFRS Farkındalıkları ve Görüşleri Üzerine Bir Çalışma", Muhasebe Bilim Dünyası Dergisi, 16/2, 110-135.

Patro, A. ve Gupta, V. K. (2012), “Adoption of International Financial Reporting Standards (IFRS) in Accounting Curriculum in India - An Empirical Study”. Procedia Economics and Finance. 2, $227-236$ 